Daśko N., Criminal protection of trademarks related to the Olympic Games, „Ekonomia i Prawo. Economics and Law.", Polszakiewicz B., Boehlke J. (ed.), Vol. 13, No. 2/2014, pp. 321-333. DOI: http://dx.doi.org/10.12775/EiP.2014.024.

\title{
NATALIA DAŚKO*
}

\section{CRIMINAL PROTECTION OF TRADEMARKS RELATED TO THE OLYMPIC GAMES}

\author{
SUMMARY
}

Intellectual property rights, especially trademarks, played an important role in organization and promotion of the Olympic Games and commercial exploitation of sport. In fact, without granting intellectual property rights related to the Olympic Games there would be nothing to be exploited and nothing to commercialize as well as no income would be generated. If there were no financial returns the sport events would not look like this these days.

As still growing part of economic value of sport is connected with intellectual property rights the protection of symbols and names related to the Olympic movement has become an important issue as it is essential for the proper functioning of the Olympic movement and efficient conducting of the next Olympic Games.

One of the research issues is an attempt to answer the question if it was right to place by the Polish legislator the petty offence consisting in the unlawful use of the Olympic symbols in the act on sport, or if it should be placed in the Petty Offence Code or should only be protected within the regulation of the act on Industrial Property Right, acts on Suppression Unfair Competition or the act on Copyrights and Related rights.

In Author's opinion placing the discussed type of offence in the act on sport was the right solution. It seems so, due to the fact that the character of this offence corresponds to the specificity of the matter regulated by this act. Thus the criminal reg-

* Natalia Daśko, Nicolaus Copernicus University, Faculty of Law and Administration, Chair of Criminl Law and Criminal Policy, ul. Władysława Bojarskiego 3, 87-100 Toruń, phone: +48 509786 022, e-mail: ndasko@doktorant.umk.pl. 
ulations of the act on sport form a consistent whole and they comprehensively regulate the given matter.

Critical remarks can be made in relation to the quality of the discussed regulation. In the first place, a change in features of the infraction in question made as part of regulations of the act on sport, consisting of adding the phrase "for commercial purposes" should be assessed critically. In this scope de lege ferenda one should be in favour of coming back to the previous legal state, which did not differentiate the unlawful use of the Olympic symbols in respect of the purpose or form.

In the article the following research methods were used: comparative method, the method of systemic analysis and the historical method. The research was based on prescriptive acts, comments and the Polish and foreign literature.

Keywords: Olympic symbols, Olympic Games, Olympic movement, criminal law, free market economy, Industrial Property Law

JEL Classification: K14, K19, K42

\section{INTRODUCTION}

Term "intellectual property" traditionally is linked to a legal system of protection of intangible goods that have significant economic importance. Thanks to the intellectual property rights holders can benefit from their creative work, and also protect the fruit against unauthorized use by others. Protection offered by intellectual property rights encourages individual and collective entity to invest time, resources, and creativity in creating innovative products that promote knowledge and culture and contribute to the progress of civilization. Protection also favors the production of high quality goods and services. Dissemination of ideas, knowledge and information necessary to stimulate innovation and growth is guaranteed mainly by patents and copyrights. Trademarks are the incentive for producers to maintain a constant level of quality of the goods bearing the signature mark $^{1}$.

Constant economic progress and highly developed free market economy cause that trademark has become the instrument of unfettered competition and the most important means of business expansion in the market ${ }^{2}$. Every day consumer is "attacked" with hundreds of different symbols by which companies operating in business trying to reach out to potential customers ${ }^{3}$.

${ }^{1}$ International Chamber of Commerce, Intellectual Property: Source of innovation, creativity, growth and progress, 2005, s. 8-9.

2 R. Skubisz, Znaki towarowe - ewolucja przedmiotu ochrony prawnej, PPH, Grudzień 2008, p. 16.

${ }^{3}$ P. Torremans, Holyoak E Torremans Intellectual Property Law, New York 2010, s. 388. 
Along with a growing importance of trademarks in conditions of free market economy it was also necessary to develop the criminal model of protection of those marks, including Olympic properties. It soon appeared that the protection of symbols and names connected with the Olympic movement is essential for the proper functioning of the Olympic movement and efficient conducting of the Olympic Games.

\section{ECONOMIC IMPORTANCE OF PROTECTION OF SYMBOLS AND NAMES RELATED TO OLYMPIC MOVEMENT}

Trademarks are important in free market economy generally and in the sport business in particular. Positive connotations and associations are the factors determining the market value of the trademark and constitute his "strength". The Olympic rings are associated with success and high standards by 81 per cent of people 4 . Trademark as an intangible property has become an active factor in reaching economic objectives. In the last 20 years branding of sports, sports events, sports clubs and teams through the application and commercialization of distinctive marks and logos has led to a new lucrative global business of sports marketing ${ }^{5}$.

All rights to any and all Olympic properties, as well as all rights to the use thereof, belong exclusively to the IOC, including but not limited to the use for any profit-making, commercial or advertising purposes. The IOC may license all or part of its rights on terms and conditions set forth by the IOC Executive Board". Article 7 Paragraph 4 of the Olympic Charter defines directly the "Olympic properties" being under protection and says who has all the property rights to them: „The Olympic symbol, flag, motto, anthem, identifications (including but not limited to "Olympic Games" and "Games of the Olympiad"), designations, emblems, flame and torches, as defined in Rules 8-14 below, may, for convenience, be collectively or individually referred to as "Olympic properties".

Licensing and merchandising rights in relation to Olympic Games has became an increasingly important issue since it provides high revenues for rights owners and concessionaires. Commercialization of sport events, such as

${ }^{4}$ P. Johson, Ambush marketing and brand protection, New York, 2011, p. 111.

${ }^{5}$ J.A.R. Nafziger, S.F. Ross, Handbook on International Sports Law, Edward Elgar Publishing, Cheltenham 2011, p. 430.

${ }_{6}^{6}$ International Olympic Committee, Olympic Charter, http://www.olympic.org/Documents/ olympic_charter_en.pdf (02.01.2014). 
the Olympic Games which could be recognized as one of the most popular sport events in general, creates high financial potential for organizers and for business community ${ }^{7}$.

IOC's Olympic marketing programme generates revenues for the Olympic Movement through several separate initiatives, like the sale of broadcast rights, Olympic Partners (TOP) worldwide sponsorship programme and the IOC's official licensing programme. For the last four years revenues from the Olympic Games in Vancouver and in London reached 8,046 billion dollars ${ }^{8}$. Nearly half of this amount comes from the sale of broadcast rights. Also, according to the program for the years 2014, 2015 and 2016, profits from transmission of the Olympic Games would reach almost 4 billion dollars 9 . Sponsorship Program allows partners to use the Olympic rights, like logos, symbols etc. throughout the world. Among the IOC partners are: Coca-cola, Visa, Samsung, Atos, McDonald's or Panasonic. Direct revenue for the Sochi 2014 Organising Committee from Licensing Programme sales exceeded 40 million dollars, with 55 licensees operating in categories such as apparel and footwear, sporting goods, household goods, accessories, stationery, souvenirs, toys and many others ${ }^{10}$. Therefore, IOC could be described as a sport and financial conglomerate and it's business.

Seeing that growing part of economic value of sport is connected with intellectual property rights, the protection of symbols and names related to the Olympic movement is needed. Effective enforcement is essential for the proper functioning of the Olympic movement and efficient conducting the next Olympic Games and also for the condition of sport economy ${ }^{11}$.

In recent decades a growing interest in the legal protection of the Olympic symbols can be observed ${ }^{12}$. An example can be the legislative action undertaken in connection with the organization of the Winter Olympic Games in Vancouver in 2010 or the Summer Olympic Games in Beijing in 2008 and the legislative work undertaken in connection with the Summer Olym-

7 J.A.R. Nafziger, S.F. Ross, op. cit, p. 430-431.

${ }^{8}$ Wprost.pl, Kto zarobi na igrzyskach w Soczi? Gtównie MKOl, http://www.wprost.pl/ ar/436811/Kto-zarobi-na-igrzyskach-w-Soczi-Glownie-MKO1 (02.03.2014).

9 A. Zalewska, Citius - Altius - Fortius, czyli szybciej - wyżej - silniej, http://www.student.lex. $\mathrm{pl} /$ czytaj/-/artykul/citius-altius-fortius-czyli-szybciej-wyzej-silniej (02.03.2014).

${ }^{10}$ International Olympic Committee, International Olympic Marketing Report Sochi 2014, Lausanne 2014, p. 23-102.

${ }^{11}$ J.A.R. Nafziger, S.F. Ross, op. cit., p. 430-431.

12 M. Leciak, Symbolika olimpijska jako przedmiot ochrony karnoprawnej, [in:] A. Błachnio-Parzych, J. Jakubowska-Hara, J. Kosonoga, H. Kuczyńska (ed.), Problemy wymiaru sprawiedliwości karnej. Ksiega jubileuszowa Profesora Jana Skupińskiego, Wolters Kluwer, Warszawa 2013, p. 268. 
pic Games in London in 2012 which resulted in the London Olympic Games and Paralympic Games Act (2006), changing the Olympic Symbol etc. (Protection) Act (1995), containing criminal regulations concerning the protection of Olympic symbols ${ }^{13}$.

The above acts have a detailed character and are related to preparations to particular Olympic Games, whereas the origin of trademark protection, including the Olympic symbols, is much older and reaches back to the $19^{\text {th }} \mathrm{c}$.

\section{INTERNATIONAL AND UE REGULATIONS}

The first significant act in the field of international trademark protection was the Paris Convention of 20 March 1883 on the protection of industrial property, being a result of international attempts concerning bringing closer the Member States legislations in the field of industrial property protection. The Convention introduced the protection of industrial property rights - of inventions, industrial patterns, trademarks, services signs, commercial names and markings of the origin. The Convention regulates the basic rules of the material and legal protection of trademarks, granting the minimal standards of protection in the area of all the States-Parties ${ }^{14}$.

However, the TRIPs (Agreement on Trade-Related Aspects of Intellectual Property Rights), making an annex to the Agreement on creating the World Trade Organization, which was created as a result of the Uruguay Round of GATT (General Agreement on Tariffs and Trade), should be regarded as the most significant and at the same time decisive act in the field of trademark protection. The previously binding acts of the international law on trademarks did not contain regulations concerning the effective and appropriate measures of pursuing and enforcing rights. TRIPs was the first, multilateral step in this direction. Provisions of TRIPs applied at the international level were introduced into the legal orders of all the Member States ${ }^{15}$.

At the UE level, one should point at two significant legal acts, namely the Council Directive of 21 December 1988, aiming at bringing closer the legislations of the Member States concerning trademarks (89/104/EEC) and the Council Regulation (EC) No. 40/94 of 1993 on the Community trade-

${ }_{13}$ Ibidem, p. 268; P. Johson, op. cit., p. 114-128.

${ }^{14}$ E.P. Winner, A.W. Denberg, International Trademark Treaties with Commentary, Oceana Publications Inc, Dobbs Ferry, New York 2004, p. 47 and next.

15 G. Tritton, Intellectual Property in Europe, Sweet \& Maxwell, London 2002, p. 196 and next. 
mark, making the result of a long-standing discussion over the shape of trademark law in the Community. The Directive was then replaced with the Directive of the European Parliament and of the Council of 22 October 2008 (2008/95/EC), whereas the Regulation No. 40/94 was consolidated by the Council Regulation (EC) No. 207/2009 of 26 February 2009 on the Community trademark.

The above act have a general character and refer to the protection of trademarks in general. The Nairobi Treaty on the protection of the Olympic symbol, adopted on 26 September 1981 (Dz. U. of 1997 No. 34, item 201) should be regarded as the most significant act of international importance which refers directly to the Olympic properties. In accordance with Art. 1 of this Treaty: "Any State party to this Treaty shall be obliged, subject to Articles 2 and 3, to refuse or to invalidate the registration as a mark and to prohibit by appropriate measures the use, as a mark or other sign, for commercial purposes, of any sign consisting of or containing the Olympic symbol, as defined in the Charter of the International Olympic Committee, except with the authorization of the International Olympic Committee. The said definition and the graphic representation of the said symbol are reproduced in the Annex"16.

The above regulations of the Nairobi Treaty correspond with the regulations contained in the Olympic Charter, particularly in its executory provisions (Art. 1 Paragraph1.1. and Paragraph 1.2) where it is pointed that IOC may take all appropriate steps to obtain the legal protection for itself, on both a national and international basis, of the rights over the Olympic Games and over any Olympic property. They also say that each NOC is responsible to the IOC for the observance, in its country, of Rules 7-14 and BLR 7-14. It shall take steps to prohibit any use of any Olympic properties which would be contrary to such Rules or their Bye-laws. It shall also endeavour to obtain, for the benefit of the IOC, protection of the Olympic properties of the $\mathrm{IOC}^{17}$.

The above legal acts imposes on the signatory states the obligation to adapt national orders to the objective regulations. The Polish legislator guaranteed a special position of the Polish Olympic Committee (PKOl) and the Polish Paralympic Committee pursuant to the act of 25 June 2010 on sport (Dz.U. No. 127, item 857, as amended). Pursuant to Art. 25 Paragraph 3 u.s. the Polish Olympic Committee has exclusive rights to use any sign or other marking consisting of the Olympic symbol or containing an Olympic sym-

${ }^{16}$ World Intellectual Property Organization, Treaty of Nairobi on protection of the Olympic symbol, http://www.wipo.int/treaties/en/ip/nairobi/trtdocs_wo018.html (01.01.2014).

${ }^{17}$ International Olympic Committee, Olympic..., op. cit. 
bol and the names: the Olympic Games, the Games of the XXX Olympiad, the Games of the XXXI Olympiad, the Games of the XXXII Olympiad, the Games of the XXXIII Olympiad, the Games of the XXXIV Olympiad, the Games of the XXXV Olympiad, the Olympic Committee, the Olympic Representation, the Olympic Movement and the Olympic Charter, whereas Art. 26 Paragraph 2 u.s. says that the Polish Paralympic Committee has exclusive rights to use the Paralympic symbols and the names: the Paralympic Games and the Paralympic Committee. The protection of this special position of the PKO1 is realized based on the provision of Art. 51 u.s. classifying the petty offence consisting on the unlawful use of the Olympic symbols and names ${ }^{18}$.

\section{PREVIOUS LEGAL STATUS}

The protection of the economic interests of PKOl related to the exclusive rights granted to them was initially realized pursuant to the act of 18 January 1996 on the physical culture (Dz.U. 1996 No. 25 item 113). Art. 57 Paragraph 1 u.k.f. said: "Who not being authorized to do that uses the Olympic symbols and names referred to in Article 11 Paragraph 3, is liable to a fine". Art. 11 Paragraph 3 stated that PKO1 has the exclusive right to use the Olympic symbols determined in the Olympic Charter and the names "The Olympic Games" and "Olympic Committee". The act in question constituted a petty offence, in consequence, the proceedings in cases for that act was regulated by the Petty Offences Procedure Code. The act provided an obligatory compensatory damages to the offender for the PKOl amounting to 100000 PLN $^{19}$.

Such a solution was assessed critically, firstly, because the amount of the compensatory damages was rigidly determined and it could not be relativized in any way to the circumstances of the particular act, and secondly, because it had an obligatory character, which also prevented the individual approach to the particular case ${ }^{20}$.

The above regulation was replaced with provisions pursuant to the act of 29 July 2005 on qualified sport (Dz. U. No. 155 item 1298 as amended). The features of the petty offence in question were not changes, and the ques-

\footnotetext{
18 Act of 25 June 2010 on sport, Dz.U. No. 127, item 857, as amended.

${ }_{19}$ Act of 18 January 1996 on the physical culture, Dz.U. 1996 No. 25 item 113.

${ }^{20}$ M. Badura (et al.), Komentarz do art. 51 ustawy o sporcie, [in:] Ustawa o sporcie. Komentarz, http://papi26.uci.umk.pl/lex/index.rpc?\&fromHistory=false\#content. rpc?nro=587317619\&wersja=-1 (01.01.2014).
} 
tion of the compensated damages was regulated differently. It had a optional character, in the amount from 50.000 PLN to 100.000 PLN $^{21}$. The introduced range of the compensatory damages already allowed adjusting its measure to the circumstances of the particular case. However, the still high lower threshold should be assessed critically ${ }^{22}$.

\section{REGULATIONS OF THE ACT ON SPORT}

The former regulations were replaced with the suitable regulation pursuant to the act of 25 June 2010 on sport (Dz. U. 2010 No. 127 item 857), which differs from the previous ones. Pursuant to Art. 51 Paragraph 1 of the act on sport: „Who, not being authorized to do this, uses for commercial purposes any sign or other marking, consisting of the Olympic or Paralympic symbol, or containing the Olympic of Paralympic symbol, and the names the Olympic Games, the Games of the XXX Olympiad, the Games of the XXXI Olympiad, the Games of the XXXII Olympiad, the Games of the XXXIII Olympiad, the Games of the XXXIV Olympiad, the Games of the XXXV Olympiad, the Olympic Committee, the Olympic Representation, the Olympic Movement, the Olympic Charter, the Paralympic Games or the Paralympic Committee, is liable to a fine"23.

In the first place, a different perspective of the causative action by the term „uses for commercial purposes” instead of the former „utilizes” is notable. The second novum is a modification of the subject matter of an attempt by a wide listing the Olympic symbols and at the first time - Paralympic symbols. Another change refers to protecting not only the Olympic symbols directly, but also signs or markings containing the Olympic of Paralympic symbols. However, the most essential modification of the regulation in question refers to the compensatory damages - leaving the optional character of the compensatory damages for the PKO1 or the Polish Paralympic Committee, the legislator decreased both the lower and the upper limits to 5000 PLN.

With reference to the subject matter of protection of the petty offence in question, it is notable that this is the only criminal regulation in the act on sport which does not refer to the question of ensuring the proper course of sport competition and its rules (cf. corruption crimes and those related to dope), but it concerns solely the protection of the economic interests of the

\footnotetext{
${ }^{21}$ Act of 29 July 2005 on qualified sport, Dz. U. No. 155 item 1298 as amended.

${ }^{22}$ M. Leciak, op. cit., p. 210.

${ }^{23}$ Act of 25 June $2010 \ldots$, op. cit.
} 
PKOl and the Polish Paralympic Committee. It is notable that the non-property and image interests of the PKOl and the Polish Paralympic Committee remain beyond the scope of protection ${ }^{24}$.

Focusing the attention on the objective side of the petty offence in question, it should be analysed what is "using in commercial purposes by a person not authorized to do this" of particular Olympic or Paralympic signs, markings and symbols in the present normative state. Firstly, it should be determined when we are deal with an unauthorized person. These will be the cases of the lack of authorization from the PKO1 or the Polish Paralympic Committee, since these are entities which have the exclusive rights (Art. 25 Paragraph 3 and Art. 26 Paragraph 2)

Then it should be considered whether the legislative action consisting in replacing the former "utilizing or using" with the only "using" limits the scope of the causative action. In the doctrine the points of view on this question are not unanimous. Some people think that the old regulation should be restored, whereas others that the feature of the "utilizing" has no other meaning but the previous feature, since on the ground of the previous regulation these terms had only synonymic character ${ }^{25}$. Consequently, now the term "using" should be understood also as "utilizing" the Olympic symbols ${ }^{26}$. This view deserves approval.

A demand for coming back to the old regulation seems to convince in the context of the phrase "for commercial purposes" placed in Art. 51 Paragraph 1 of the act on sport. In the present legal state, the perpetrator's behaviour involving the unlawful use for commercial purposes of any materials containing the Olympic symbols is subjected to penalization. Thus it is about all activities connected with selling and introducing into circulation articles or services, turning towards making profit ${ }^{27}$. Thus other business activities, which are not commercial activities, e.g. earning, manufacturing, service and building activities, remain beyond the scope of penalization. It is rightly noticed in the doctrine that the concept of business activity is considerable broader than commercial activity, whereas the service activity is something completely different ${ }^{28}$. In accordance with the fundamental rule of the criminal law, nullum crimen sine lege - when there will happen an unauthorized use of the Olym-

24 M. Badura (et al.), op. cit.

${ }^{25}$ Cf. M. Szymczak (red.), Stownik Jezzyka Polskiego PWN, Warszawa 1995; hasło „używać” i „wykorzystywać”.

${ }^{26}$ M. Badura (et al.), op. cit.

27 Ibidem.

${ }^{28}$ W. Cajsel, Ustawa o sporcie. Komentarz, https://sip.legalis.pl/document-view.seam?document $\mathrm{Id}=$ mjxw62zoge2tkmbvgi4dmmroobqxalrrgmydqobzgy2q\&conversationId=92945 (28.12. 2013). 
pic symbols e.g. by a businessman during the hotel activity (e.g. marking hotel accessories with Olympic symbols) or as part of the non-profit activity the features of the petty offence in question will not be realized ${ }^{29}$.

Therefore it seems to be legitimate to call for coming back to the previous legal state, where each unauthorized use of the Olympic symbols was penalized, regardless of the purpose and form of such action. M. Leciak rightly notices that the shape of the present regulation pursuant to u.s. results directly from the content of the Nairobi Treaty. However, the same Treaty was not an obstacle for other states to adopting a wider model of the criminal protection of the Olympic symbols than the Polish one ${ }^{30}$.

Then it should be noted that the use of the phrase "for commercial purposes" by the legislator determines the operational character of the given petty offence and each time imposes the obligation to prove in the proceedings dolus directus coloratus, which certainly creates unnecessary evidence difficulties.

The perpetrator of the petty offence in question can be every natural person, thus it has a common character. The act uses the term "who" - thus everyone, the condition of liability is only that the businessman or another natural person, acted for commercial purposes.

A serious drawback of the objective regulation is the fact that the offender cannot be a collective entity (e.g. companies running commercial activity unlawfully using the Olympic symbols). The condition of liability for a petty offence is committing an "act" - thus it is only about the person's behaviour. The legal person cannot be an offender, and the act of 28 October 2002 on liability of collective entities for the acts prohibited under penalty (Dz. U. 2002 No. 197 item 1661) has no application to petty offences, only to crimes or treasury crimes.

The objective offence has a formal character, which means that de facto damage not have to be done to the PKO1 or to the Polish Paralympic Committee, which, however, seems to be inevitable ${ }^{31}$. Then it should be stated that the petty offence in the form of unlawful use of the Olympic symbols can be committed only by action, not by abandonment ${ }^{32}$.

The offence from Article 51 Paragraph 1 of the act of sport is liable to a fine from 20 to 5000 PLN (Art. $24 \S 1$ of the Petty Offence Code). Such a regulation deserves a definite criticism. In practice, this type of act is committed by businessmen or organized groups rather than by single people.

\footnotetext{
${ }^{29}$ M. Leciak, op. cit., p. 273.

${ }^{30}$ Ibidem.

${ }^{31}$ Ibidem.

32 W. Cajsel, op. cit.
} 
The forbidden activity the most often involves signing articles with the Olympic symbols in order to introduce them to circulation or using for advertising. In each case, however, this is about an action directed to achieving profit. Therefore it can be stated easily that the fine amounting up to 5000 PLN does not make a real problem to such an entity. For comparison, British solutions can be given, where the fine provided amounts up to 20 thousand pounds ${ }^{33}$.

Additionally, a compensatory damages can be pronounced to the offender for PKO1 or the Polish Paralympic Committee, amounting up to 5000 PLN. It has a facultative character. Its amount also should be subjected to criticism, since it completely incompatible with the conditions of free market economy. A potential businessman, e.g. operating on the Internet portals, can during a certain period achieve a profit considerably exceeding the amount of the compensatory damages, hence it will not have a repressive character and in many cases it will not force them to cease carrying on such activities ${ }^{34}$.

\section{CONCLUSION}

Summing up the above remarks, it should be said in the first place that the creation of the criminal model of trademark protection at the international level - including the Olympic symbols - was an right move. It is evident that at the dynamic development of free market economy, the institution of trademarks is of utmost importance. Forging and altering trademarks and their unlawful use are usually done on a large scale. Therefore it is necessary to protect them, also by the criminal law. It is also true that sport is now big business and big business demand this protection.

For these reasons, it is also worth considering if it would not be a better solution to transform the discussed type of the prohibited act in question into a crime and through amendments of the act on liability of collective entities to prosecute also those collective entities. It seems that behaviours described in Art. 51 paragraph 1 of the act on sport are undertaken in definite majority by those collective entities which, however, do not fall under the scope of this regulation.

On the other hand, the model of criminal protection of the Olympic symbols should be assessed comprehensively and it should be noticed that apart

33 London Olympic Games and Paraolympic Games Act 2006, http://www.legislation.gov.uk/ukpga/2006/12/schedule/3 (27.122013).

${ }^{34}$ W. Cajsel, op. cit. 
from the detailed regulation of Art. 51 Paragraph 1, more general provisions may have application, concerning the criminal protection of trademarks from the act of 30 June 2000. The Industrial Property Law- Art. 305 (consolidated text Dz. U. of 2003 No. 119 item 1117 as amended), the act of 16 April 1993 on Suppressing Unfair Competition (consolidated text: Dz. U. of 2003 No. 153 item 1503 as amended), the act of 4 February 1994 on the Copyrights and Related rights (consolidated text Dz. U. of 2006 No. 90 item 631 as amended) or from the Criminal Code (Art. 291). In the case of some pointed regulations it is possible to bring collective entities to justice (see Art. 16 Paragraph 1 of the act on liability of collective entities under penalty).

That being so, one should think whether to place the type of offence under discussion in the act on sport was the right solution. It seems so, because the character of this offence corresponds to the specificity of the matter which is regulated by this act. Therefore it is a logical solution that the offence consisting in the unlawful use of the Olympic symbols can be found exactly in the act on sport. Thus the criminal regulations of the act on sport form a consistent whole and they comprehensively regulate the given matter.

Critical remarks can also be made in relation to the quality of the objective regulation. In the first place, a change in features of the petty offence in question made as part of regulations of the act on sport, and consisting in adding the phrase "for commercial purposes" should be assessed critically. Such a legislative step certainly reduces the range of application of the new criminal regulation, because - which was discussed - the unlawful use of Olympic symbols within the framework of business activity other than commercial remains beyond penalization. In this scope de lege ferenda one should be in favour of coming back to the previous legal state, which did not differentiate the unlawful use of the Olympic symbols in respect of the purpose or form.

\section{BIBLIOGRAPHY}

Act of 18 January 1996 on the physical culture, Dz.U. 1996 No. 25 item 113. Act of 25 June 2010 on sport, Dz.U. No. 127, item 857. Act of 29 July 2005 on qualified sport, Dz. U. No. 155 item 1298.

Badura M. (et al.), Komentarz do art. 51 ustawy o sporcie, [in:] Ustawa o sporcie. Komentarz, http://papi26.uci.umk.p1/lex/index.rpc?\&fromHistory=false\#content. rpc?nro $=587317619 \& w e r s j a=-1(01.01 .2014)$.

Cajsel W., Ustawa o sporcie. Komentarz, https://sip.legalis.pl/document-view.seam?d ocumentId=mjxw62zoge2tkmbvgi4dmmroobqxalrrgmydqobzgy2q\&conversation $\mathrm{Id}=92945$ (28.12.2013). 
International Chamber of Commerce, Intellectual Property: Source of innovation, creativity, growth and progress, 2005.

International Olympic Committee, International Olympic Marketing Report Sochi 2014, Lausanne 2014.

International Olympic Committee, Olympic Charter, http://www.olympic.org/Documents/olympic_charter_en.pdf (02.01.2014).

Johson P., Ambush marketing and brand protection, New York, 2011.

Leciak M., Symbolika olimpijska jako przedmiot ochrony karnoprawnej, [in:] A. Błachnio-Parzych, J. Jakubowska-Hara, J. Kosonoga, H. Kuczyńska (ed.), Problemy wymiaru sprawiedliwości karnej. Ksiega jubileuszowa Profesora Jana Skupińskiego, Wolters Kluwer, Warszawa 2013.

London Olympic Games and Paraolympic Games Act 2006, http://www.legislation.gov.uk/ ukpga/2006/12/schedule/3 (27.12.2013).

Nafziger J.A.R., Ross S.F., Handbook on International Sports Law, Edward Elgar Publishing, Cheltenham 2011.

Skubisz R., Znaki towarowe - ewolucja przedmiotu ochrony prawnej, PPH, Grudzień 2008.

Szymczak M. (red.), Stownik Jezyka Polskiego PWN, Warszawa 1995.

Torremans P., Holyoak \& Torremans Intellectual Property Law, New York 2010.

Tritton G., Intellectual Property in Europe, Sweet \& Maxwell, London 2002.

Winner E.P., Denberg A.W., International Trademark Treaties with Commentary, Oceana Publications Inc, Dobbs Ferry, New York 2004.

World Intellectual Property Organization, Treaty of Nairobi on protection of the Olympic symbol, http://www.wipo.int/treaties/en/ip/nairobi/trtdocs_wo018.html (01.01.2014).

Wprost.pl, Kto zarobi na igrzyskach w Soczi? Gtównie MKOl, http://www.wprost.pl/ ar/436811/Kto-zarobi-na-igrzyskach-w-Soczi-Glownie-MKO1 (02.03.2014).

Zalewska A., Citius - Altius - Fortius, czyli szybciej - wyżej - silniej, http://www. student.lex.pl/czytaj/-/artykul/citius-altius-fortius-czyli-szybciej-wyzej-silniej (02.03.2014). 